J. AMER. Soc. Hort. SCI. 115(4):570-574. 1990.

\title{
Lime and Phosphorus Effects on American Ginseng: I. Growth, Soil Fertility, and Root Tissue Nutrient Status Response
}

\author{
T.R. Konsler ${ }^{1}$ and J.E. Shelton ${ }^{2}$ \\ North Carolina State University, Raleigh, NC 27695-7609 \\ Additional index words. Panax quinquefolium, root nutrients
}

\begin{abstract}
Soil applications of dolomitic limestone and $\mathbf{P}$ fertilizer before seeding American ginseng (Panax quinquefolium L.) affected root weight (RW) gain during the first 4 years of growth. At the end of each growing season, root size was greatest with the intermediate liming rate and with the high $P$ rate. Lime resulted in positive linear responses in soil $\mathrm{pH}, \mathrm{K}, \mathrm{Ca}$, and $\mathrm{Mg}$ and in root $\mathrm{N}, \mathrm{P}, \mathrm{Ca}$, and $\mathrm{Mg}$ and curvilinear responses in soil $\mathrm{Mn}$ and $\mathrm{Zn}$ and in root $\mathrm{K}$, Mn, and Zn. Applied $\mathrm{P}$ had a positive linear effect on soil $\mathrm{Na}$ and on root $\mathrm{N}$, $\mathrm{Ca}$, and $\mathrm{Fe}$ and a curvilinear effect on soil $P$ and on root $P$ and $\mathrm{Ca}$. Terminal $R W$ was positively correlated with soil $\mathrm{pH}, \mathrm{K}, \mathrm{Ca}, \mathrm{Mg}$, and $\mathrm{Na}$ and with root $\mathrm{P}, \mathrm{K}$, Ca, and Mg; RW was negatively correlated with root Mn and Zn. Regression analyses implicated only soil $\mathrm{Ca}$ and $\mathrm{Na}$ and root $\mathrm{Mg}$ and $\mathrm{Zn}$ as significant terms in prediction equations,
\end{abstract}

American ginseng is native to the hardwood-forested regions of eastern North America. It ranges from southeastern Canada southward to the Carolinas and Georgia and westward to states bordering the Mississippi River (Nash, 1898). Soils within this region vary in acidity and fertility. Roberts and Richardson (1981) sampled soil in sixty-four 0.4-ha sites in 12 Kentucky counties surveyed for native ginseng. Of 60 sites where ginseng was found, soil $\mathrm{pH}$ ranged from 4.5 to $7.4, \mathrm{P}$ varied from 4.5 to $135 \mathrm{~kg} \cdot \mathrm{ha}^{-1}$, and $\mathrm{K}$ ranged from 118 to $411 \mathrm{~kg} \cdot \mathrm{ha}^{-1}$. Woodland soils from sites in North Carolina associated with native ginseng were acid ( $\mathrm{pH} 4.4$ to 5.1), low in $\mathrm{P}$ content (4.5 to $20.2 \mathrm{~kg} \cdot \mathrm{ha}^{-1}$ ),

Received for publication 13 Mar. 1989. Paper no. 12055 of the Journal Series of the North Carolina Agricultural Research Service, Raleigh, NC 27695-7643. Technical assistance by George Cox, Ag. Res. Tech. I, is gratefully acknowledged. Mention of a proprietary product or vendor does not imply endorsement by North Carolina Agricultural Research Service nor criticism of similar ones not mentioned. The cost of publishing this paper was defrayed in part by the payment of page charges. Under postal regulations, this paper therefore must be hereby marked advertisement solely to indicate this fact.

${ }^{1}$ Professor Emeritus, Dept. of Horticultural Science.

${ }^{2}$ Associate Professor, Dept. of Soil Science. and moderately high in $\mathrm{K}$ (65 to $267 \mathrm{~kg} \cdot \mathrm{ha}^{-1}$ ) (unpublished data). Hartman (1979) reported that the $\mathrm{pH}$ range of native soils in Marathon County, Wis., the center of commercial ginseng production in the United States, was 5.0 to 5.5 , but that growers often grew ginseng immediately following alfalfa, which normally was limed to a $\mathrm{pH}$ of 6.5 to 6.9. Khwaja et al. (1984) analyzed soil samples and root and leaf tissue from commercial ginseng plantings in Wisconsin of different age, level of productivity, and apparent nutritional status. Soil $\mathrm{pH}$ ranged from 6.7 to 8.1 and soil $\mathrm{P}$ varied from 98 to $191 \mathrm{~kg} \cdot \mathrm{ha}^{-1}$.

Ginseng has been cultivated in North America since the late 19th Century (Nash, 1898); however, the scientific study of its nutritional needs and other cultural requirements has been largely neglected. Stolz (1981, 1982a) obtained smaller RW increases in 2nd-year plants by withholding $\mathrm{N}, \mathrm{P}, \mathrm{Ca}$, or $\mathrm{Mg}$ from nutrient solutions in sand culture. Absence of $\mathrm{Ca}$ was more restrictive of root growth and resulted in earlier foliar deficiency symptoms than the absence of other elements.

Root growth and foliar color were positively related to $\mathrm{N}$ rate

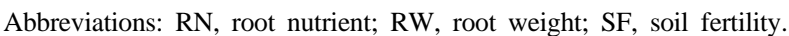


in sand culture where $\mathrm{N}$ was derived from $\mathrm{NH}_{4}$ and $\mathrm{NO}_{3}$ in the proportion 1:14 (w/w) (Stolz, 1982b). Changing the proportion of $\mathrm{N}$ from those respective sources to $3: 12$ or to $0: 15$ caused no visual symptoms but reduced root growth. Root growth was positively correlated with $\mathrm{P}$ content of the solution. Elimination of $\mathrm{Ca}$ resulted in an increased incidence of root rot and earlier foliar senescence. Root growth increased with $\mathrm{Ca}$ to a $1 \times$ rate in the solution and was less at a $1.5 \times$ level, indicating a curvilinear response.

A 4-year experiment was initiated in 1978 to measure ginseng root growth and tissue nutrient element response to lime and $\mathrm{P}$ additions to a low $\mathrm{pH} /$ low $\mathrm{P}$ soil. Nitrogen also was a variable in the experiment; however, growth response to $\mathrm{N}$ was minor and will not be considered in this report.

\section{Materials and Methods}

Topsoil from a wooded site on the Mountain Horticultural Crops Research Station, Fletcher, N.C., was used for this study. The soil was a Hayesville loam (clayey, oxidic, mesic Typic Hapludults) with the following nutritional status as determined by the Mehlich III extraction process (Agronomic Division, N.C. Dept. of Agr., Raleigh): $\mathrm{pH}=4.3, \mathrm{P}=17 \mathrm{mg} \cdot \mathrm{dm}^{-3}, \mathrm{~K}=$ $0.25 \mathrm{meq} / 100 \mathrm{~cm}^{3}, \mathrm{Ca}=0.80 \mathrm{meq} / 100 \mathrm{~cm}^{3}, \mathrm{Mg}=0.24 \mathrm{meq} /$ $100 \mathrm{~cm}^{3}, \mathrm{Mn}=10.4 \mathrm{mg} \cdot \mathrm{dm}^{-3}, \mathrm{Na}=0.06 \mathrm{meq} / 100 \mathrm{~cm}^{3}$. The soil was steam sterilized, screened, and batches were amended with three rates each of dolomitic limestone $\left[\mathrm{Ca}-\mathrm{Mg}\left(\mathrm{CO}_{3}\right)_{2}\right](0$, 4.42 , and $\left.8.84 \mathrm{~kg} \cdot \mathrm{m}^{-3}\right)$ and super-phosphate fertilizer $(0 \mathrm{~N}-8.7 \mathrm{P}$ $0 \mathrm{~K})\left(0,0.16\right.$, and $\left.0.32 \mathrm{~kg} \mathrm{P} / \mathrm{m}^{3}\right)$ in factorial combination. (Note: The terms, "lime" and "phosphorus" will be used interchangeably with dolomitic limestone and superphosphate fertilizer, respectively.) Four-liter nursery pots with $2 \mathrm{~cm}$ of stone drainage were filled with each soil mix. Each plot consisted of one pot. Treatments were arranged in a RCB design and replicated 10 times.

Ten stratified seeds were planted equidistant around the periphery of each pot in Apr. 1978. Pots were placed outdoors on the ground from April to November each year under $75 \%$ wood lath shade supported $2 \mathrm{~m}$ above the soil surface and overwintered on the concrete floor of an enclosed, unheated building. Pots were watered with overhead irrigation as needed to maintain desired soil moisture. Pest control included weekly applications of mancozeb $80 \mathrm{~W}$ (manganous ethylenebisdithiocarbamate + zinc ion) at $0.24 \mathrm{~kg} / 100$ liter from May through August each year for control of ginseng blight (Alternaria panax Whet.) and distribution of bait pellets [3.25\% metaldehyde and $4.25 \%$ carbaryl (1-naphthyl methylcarbamate)] around the pots for control of slugs.

Roots were dug in October or November each year, washed free of soil, weighed, dipped in a suspension of captan $50 \mathrm{~W}$ fungicide (3.6 g.liter ${ }^{-1}$ ) and replanted in the soil of their respective pots. The population was adjusted to three representative roots per pot at the end of the first growing season and to two at the end of the second. Each year, one or two replicates were used for tissue and soil testing. Final growth results were based on five replications. At termination of the experiment, roots from three replicates were analyzed for nutrient status (Agronomic Division, N.C. Dept. of Agr., Raleigh). Standard statistical procedures (Steel and Torrie, 1960) were used to analyze root growth response to treatment and to calculate correlations among soil fertility factors, root growth measurements, and ginseng root nutrient levels. Correlations and regression analyses involving tissue nutrients were based on the three rep- licates analyzed for nutrient status. All root size data are fresh weights unless specified otherwise.

\section{Results and Discussion}

First- and second-year responses to lime and $\mathrm{P}$ treatments were reported earlier (Konsler, 1979, 1980; Konsler and Shelton 1980). After one growing season, lime and $P$ treatments resulted in average soil $\mathrm{pH}$ levels of 4.4, 5.5, and 6.5 and $\mathrm{P}$ concentration of 38, 196, and $464 \mathrm{~kg} \cdot \mathrm{ha}^{-1}$, respectively (Konsler, 1979). At 1 and 2 years of age, roots grown in soil at $\mathrm{pH} 5.5$ were about double the weight of those grown at 4.4 ( $0.58 \mathrm{~g}$ vs. 0.27 $\mathrm{g}$ and $4.06 \mathrm{~g}$ vs. $1.98 \mathrm{~g}$ for years 1 and 2, respectively); at $\mathrm{pH}$ 6.5 , roots were $59 \%$ and $29 \%$ larger at ages 1 and 2 years, respectively, than those grown in nonlimed soil (Konsler, 1979, 1980). Soil P level and RW were positively correlated; with the highest $\mathrm{P}$ level, roots were $33 \%$ and $47 \%$ larger at 1 and 2 years of age, respectively, than roots with no added P. Seedling roots were more regularly "spindle-shaped" with the intermediate rate of lime (Konsler, 1979; Konsler and Shelton, 1980).

At termination of the experiment, soil $\mathrm{pH}$ and $\mathrm{P}$ status had changed only slightly relative to the initial year. Lime treatments resulted in average terminal $\mathrm{pH}$ levels of 4.6, 5.5, and 6.4, while $\mathrm{P}$ differentials resulted in average $\mathrm{P}$ levels of 56, 200, and $377 \mathrm{~kg} \cdot \mathrm{ha}^{-1}$.

Root growth. The annual rate of RW gain for all treatments

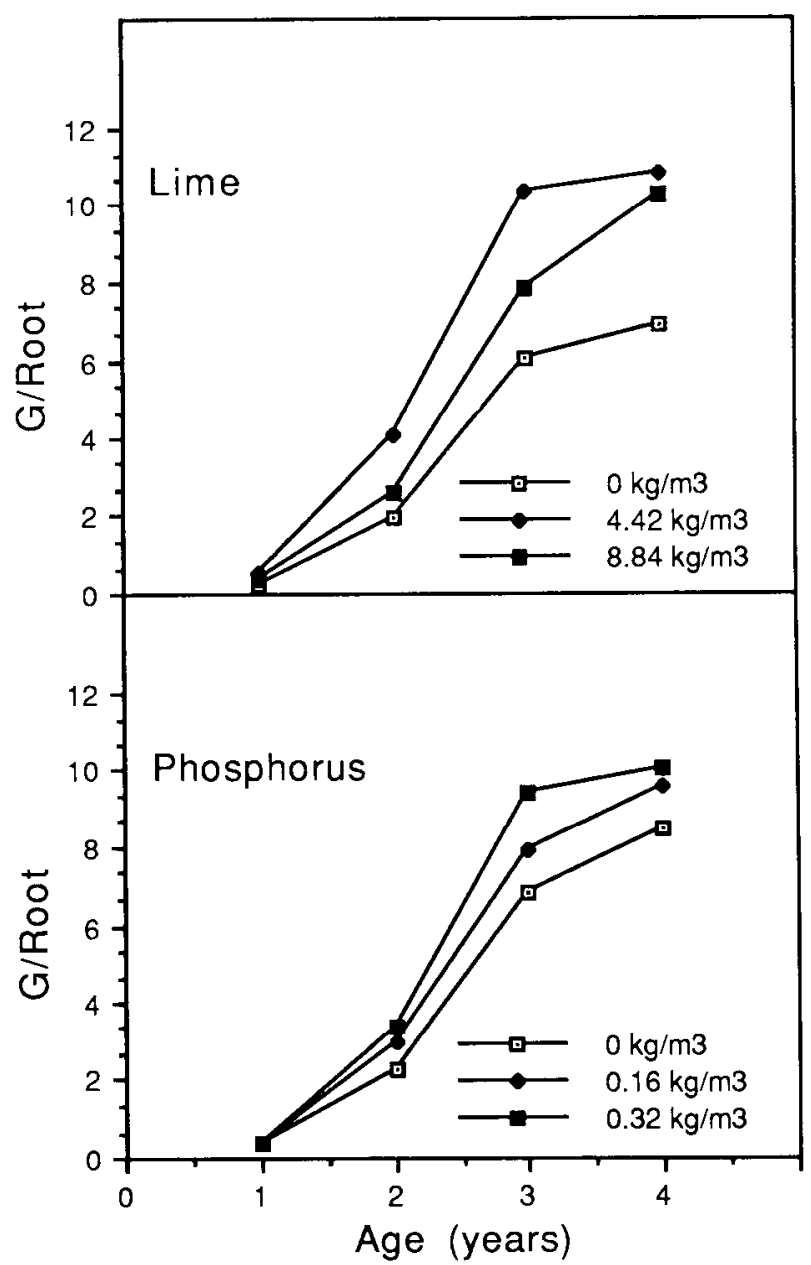

Fig. 1. Ginseng RW (g/root) response through 4 years to additions of dolomitic limestone and $\mathrm{P}$ (from $0 \mathrm{~N}-8.7 \mathrm{P}-0 \mathrm{~K}$ superphosphate fertilizer) to the potting medium. LSD (0.05) for year $1=0.03,2$ $=0.22,3=0.67,4=0.94$. 
increased with age through the third growing season and was reduced during the 4th year, resulting in a sigmoid ( $\mathrm{S}$-shaped) growth curve for each lime or $\mathrm{P}$ treatment (Fig. 1). A sigmoid growth curve is typical of many biological systems (Bakhuyzen, 1926; von Bertalanffy, 1957). Reduced growth rate during the 4th year (Fig. 1) may have been partially due to limitation in pot size. However, the shape of the growth curves was not atypical for high plant populations of ginseng, including populations typical of commercial production. Hartman (1979) reported seeding rates of 78 to $157 \mathrm{~kg} \cdot \mathrm{ha}^{-1}$ among commercial growers in Wisconsin, or up to 275 seeds $/ \mathrm{m}^{2}$. In a plant population study in ground beds, 4th-year growth rates were reduced relative to the 3 rd-year rate for plant populations of 258 , 86 , or 43 plants $/ \mathrm{m}^{2}$ but not for 29 plants $/ \mathrm{m}^{2}$ (Konsler, 1982).

Fourth-year RW was affected by both lime and P treatments. RW increased linearly with $\mathrm{P}$ and was curvilinear with lime (Table 1). Maximum RW was associated with the median lime and high $\mathrm{P}$ levels. RW response to lime and $\mathrm{P}$ was qualitatively the same each year (Fig. 1).

Soil fertility response to treatment. Addition of dolomitic limestone and $\mathrm{P}$ fertilizer to soil affected not only the soil acidity

Table 1. RW response of 4-year-old ginseng to soil dolomitic limestone (lime) and $\mathrm{P}$ additions.

\begin{tabular}{lc}
\hline $\begin{array}{c}\text { Addition } \\
\left(\mathrm{kg} \cdot \mathrm{m}^{-3}\right)\end{array}$ & $\begin{array}{c}\mathrm{Wt} / \mathrm{root} \\
(\mathrm{g})\end{array}$ \\
\hline $\mathrm{Lime}^{\mathrm{z}}$ & \\
0.0 & 7.53 \\
4.42 & 10.9 \\
8.84 & 10.3 \\
$\mathrm{P}^{z}$ & \\
0.0 & 8.67 \\
0.16 & 9.54 \\
0.32 & 10.8 \\
Significancey & \\
$\quad$ Lime & $\mathrm{L}^{\mathrm{a}} \mathrm{Q}^{\mathrm{a}}$ \\
$\mathrm{P}$ & $\mathrm{L}^{\mathrm{a}}$ \\
Interaction & $\mathrm{NS}$ \\
\hline
\end{tabular}

${ }^{\mathrm{z}}$ Rates applied to potting medium at initiation of the experiment. ${ }^{\mathrm{y}} \mathrm{L}=$ linear; $\mathrm{Q}=$ quadratic.

${ }^{\mathrm{NS}}$, Nonsignificant or significant at $P=0.001$, respectively.
(pH) and P levels, but also caused changes in other SF factors (Table 2). Dolomitic limestone contributed $\mathrm{Ca}$ and $\mathrm{Mg}$ directly to the soil. Soil $\mathrm{Ca}$ and $\mathrm{Mg}$ were linearly related to liming rate, as was soil K. Manganese and zinc were curvilinear in their response to lime, and neither $\mathrm{P}$ nor $\mathrm{Na}$ was affected by liming rate (Table 2). Phosphorus applications resulted in a linear increase in soil $\mathrm{P}$ with a significant quadratic component (Table 2). Phosphorus also affected soil Na. Such interactions between lime or fertilizer additions to soil and nutrient status of other factors in the soil are not unusual (Bear, 1964; Pearson and Adams, 1967).

Root weight vs. soil fertility. Ginseng root growth was affected by lime and $\mathrm{P}$ treatments (Table 1); however, it is reasonable to assume that nutrition and growth were more directly related to the overall SF status resulting from the fertilizer applications.

Simple correlations between RW and each SF factor were computed to identify factors related to root growth. RW was positively correlated with soil $\mathrm{pH}, \mathrm{K}, \mathrm{Ca}, \mathrm{Mg}$, and $\mathrm{Na}$ (Table 3). Soil P, Mn, and $\mathrm{Zn}$ were not significantly correlated with terminal RW. A multiple regression analysis was performed with RW on the five factors with which it was correlated. Nonsignificant terms in the equation were deleted in sequence (Regress II: A Multiple Regression Program for Apple II/II E; Human Systems Dynamics) until only significant $(P \leq 0.05)$ ones remained. The resulting equation:

$$
\mathrm{RW}=1.783 \mathrm{Ca}-0.128 \mathrm{Ca}^{2}+97.619 \mathrm{Na}-1.295
$$

with an $R^{2}$ of $0.56(P=0.001)$, suggests that $\mathrm{Ca}$ and $\mathrm{Na}$ were important SF factors in affecting terminal RW. For any fixed level of $\mathrm{Na}$, the equation predicts an increase in RW with increasing $\mathrm{Ca}$ to $7.0 \mathrm{meq} / 100 \mathrm{~cm}^{3}$, then a decrease in root size with any further $\mathrm{Ca}$ increase. Thus, predicted response to $\mathrm{Ca}$ was in agreement with response to lime (Table 1) and the sand culture findings of Stoltz $(1981,1982 a)$ who concluded that Ca was important to root growth and whose results showed a curvilinear response (1982b).

We found no studies investigating the role of $\mathrm{Na}$ in ginseng root growth.

Tissue nutrient response to treatment. Crop fertility recommendations often are based on tissue nutrient levels-generally

Table 2. Terminal SF status associated with three rates each of dolomitic limestone (lime) and $\mathrm{P}$ in a pot experiment with American ginseng.

\begin{tabular}{|c|c|c|c|c|c|c|c|c|}
\hline \multirow{2}{*}{$\begin{array}{l}\text { Addition } \\
\left(\mathrm{kg} \cdot \mathrm{m}^{-3}\right)\end{array}$} & \multirow[b]{2}{*}{$\mathrm{pH}$} & \multicolumn{7}{|c|}{ Nutrient element } \\
\hline & & $\mathrm{P}$ & $\mathrm{Mn}$ & $\mathrm{Zn}$ & $\mathrm{K}$ & $\mathrm{Ca}$ & $\mathrm{Mg}$ & $\mathrm{Na}$ \\
\hline & & \multicolumn{3}{|c|}{$m g \cdot d m^{-3}$} & \multicolumn{4}{|c|}{$m e q / 100 \mathrm{~cm}^{3}$} \\
\hline \multicolumn{9}{|l|}{$\operatorname{Lime}^{z}$} \\
\hline 0.0 & 4.6 & 91 & 12.0 & 3.3 & 0.23 & 2.2 & 0.44 & 0.056 \\
\hline 4.42 & 5.5 & 94 & 8.5 & 3.4 & 0.25 & 5.2 & 0.51 & 0.061 \\
\hline 8.84 & 6.4 & 97 & 12.0 & 2.2 & 0.29 & 9.0 & 0.57 & 0.068 \\
\hline \multicolumn{9}{|l|}{$\mathrm{P}^{2}$} \\
\hline 0.0 & 5.5 & 25 & 10.1 & 2.7 & 0.27 & 5.1 & 0.52 & 0.058 \\
\hline 0.16 & 5.5 & 89 & 11.0 & 3.0 & 0.25 & 5.4 & 0.47 & 0.061 \\
\hline 0.32 & 5.5 & 168 & 11.4 & 3.2 & 0.26 & 5.9 & 0.52 & 0.064 \\
\hline \multicolumn{9}{|l|}{ Significance ${ }^{y}$} \\
\hline Lime & $\mathrm{L}^{\mathrm{a}}$ & NS & $\mathrm{L}^{\mathrm{h}} \mathrm{Q}^{\mathrm{a}}$ & $\mathrm{L}^{c} \mathrm{Q}^{\mathrm{a}}$ & $\mathrm{L}^{\mathrm{a}}$ & $\mathrm{L}^{\mathrm{a}}$ & $\mathrm{L}^{\mathrm{a}}$ & NS \\
\hline$P$ & NS & $\mathrm{L}^{a} \mathrm{Q}^{\mathrm{c}}$ & NS & NS & NS & NS & NS & $\mathrm{L}^{\mathrm{c}}$ \\
\hline $\mathrm{R}$ (lime) & $0.89^{a}$ & NS & $0.47^{b}$ & $0.78^{a}$ & $0.63^{\mathrm{a}}$ & $0.97^{\mathrm{a}}$ & $0.49^{\mathrm{a}}$ & NS \\
\hline $\mathrm{R}(\mathrm{P})$ & NS & $0.98^{\circ}$ & NS & NS & NS & NS & NS & $0.30^{c}$ \\
\hline
\end{tabular}

${ }^{\mathrm{Z}}$ Rates applied to potting medium at initiation of the 4-year experiment.

${ }^{\mathrm{y}} \mathrm{L}=$ linear; $\mathrm{Q}=$ quadratic; $\mathrm{R}=$ multiple correlation coefficient.

${ }^{\mathrm{NS}, \mathrm{a}, \mathrm{b}, \mathrm{c}}$ Nonsignificant or significant at $P=0.001,0.01$, or 0.05 , respectively. 
Table 3. Correlation ( $r$ ) between SF factors or RN elements and RW of 4-year-old American ginseng.

\begin{tabular}{lcccccccccccc}
\hline \hline \multicolumn{10}{c}{ Fertility factors and nutrient elements } \\
\hline & $\mathrm{pH}$ & $\mathrm{N}$ & $\mathrm{P}$ & $\mathrm{K}$ & $\mathrm{Ca}$ & $\mathrm{Mg}$ & $\mathrm{Mn}$ & $\mathrm{Zn}$ & $\mathrm{Cu}$ & $\mathrm{Na}$ & $\mathrm{Fe}$ \\
\hline $\mathrm{r}_{\mathrm{SF}}$ & $0.58^{\mathrm{a}}$ & $\cdots$ & $\mathrm{NS}$ & $0.55^{\mathrm{a}}$ & $0.59^{\mathrm{a}}$ & $0.50^{\mathrm{a}}$ & $\mathrm{NS}$ & $\mathrm{NS}$ & $\cdots$ & $0.69^{\mathrm{a}}$ & $\cdots$ \\
$\mathrm{r}_{\mathrm{RN}}$ & $\cdots$ & $\mathrm{NS}$ & $0.66^{\mathrm{a}}$ & $0.66^{\mathrm{a}}$ & $0.66^{\mathrm{a}}$ & $0.67^{\mathrm{a}}$ & $-0.70^{\mathrm{a}}$ & $-0.68^{\mathrm{a}}$ & $\mathrm{NS}$ & $\cdots$ & $\mathrm{NS}$ \\
\hline
\end{tabular}

from leaf tissue samples (Ulrich, 1976). In the present study, expendable, treated ginseng plants were not available nor was foliage on record plants adequate for tissue sampling during the growing season. Therefore, leaf tissue was not analyzed for nutrient content. However, root tissue from record plants was not restricted in quantity and samples were analyzed for content of $\mathrm{N}, \mathrm{P}, \mathrm{K}, \mathrm{Ca}, \mathrm{Mg}, \mathrm{Mn}, \mathrm{Zn}, \mathrm{Cu}$, and $\mathrm{Fe}$.

Lime treatments resulted in significant changes in most RN elements analyzed. There was a general increase in root $\mathrm{N}, \mathrm{P}$, $\mathrm{K}, \mathrm{Ca}$, and $\mathrm{Mg}$ and a decrease in root $\mathrm{Mn}$ and $\mathrm{Zn}$ with increased lime (Table 4). The changes in root $\mathrm{K}, \mathrm{Mn}$, and $\mathrm{Zn}$ had a nonlinear component to their response. Neither $\mathrm{Cu}$ nor Fe was affected by lime treatments.

Soil $\mathrm{P}$ additions resulted in general increases in root $\mathrm{N}, \mathrm{P}$, $\mathrm{Ca}$, and $\mathrm{Fe}$ and a decrease, at the high rate, in root $\mathrm{Cu}$ (Table 4). Both root $\mathrm{Cu}$ and root $\mathrm{P}$ responses were curvilinear with maximum levels falling within the range of $P$ treatments applied. Root $\mathrm{Mg}, \mathrm{Mn}$, and $\mathrm{Zn}$ were not affected by $\mathrm{P}$ treatments.

Interrelationships among soil fertility factors and root nutrient elements. There were some general similarities in RN and $\mathrm{SF}$ responses to lime and P treatments. Disregarding departures from strict linearity in some instances, additions of lime caused increases in both soil and root $\mathrm{K}, \mathrm{Ca}$, and $\mathrm{Mg}$ and decreases in Zn (Tables 2 and 4). Manganese response was curvilinear with a concave upward attitude in both sites; however, the change in Mn level in root tissue was much greater than in soil. Lime caused no change in $\mathrm{P}$ content of the soil but resulted in a linear increase in this element in the root tissue. Zinc was lowered by the high rate of lime in the soil and in root tissue; however, soil response was concave downward, while root response was concave upward.

Among the six elements analyzed that were common to both soil and root tissue (P, K, Ca, Mg, Mn, Zn), applied P affected only soil $\mathrm{P}$, causing an increase in this element (Table 2). Root $P$ also increased with rate of $P$ applied (Table 4), as did root $\mathrm{Ca}$. Root $\mathrm{K}, \mathrm{Mg}, \mathrm{Mn}$, and $\mathrm{Zn}$ were not affected by $\mathrm{P}$ treatment.

Roof weight vs. root nutrients. Simple correlations were calculated for RW with each of the nine RN elements. Positive correlations of RW with $\mathrm{P}, \mathrm{K}, \mathrm{Ca}$, and $\mathrm{Mg}$ (Table 3) suggest the possible importance of these elements to ginseng root growth. Negative correlations with tissue $\mathrm{Mn}$ and $\mathrm{Zn}$ suggest the possibility of their detriment to growth with increased tissue content.

The relationship of RW with RN elements was similar in some respects to its relationship with SF factors (Table 3); RW was positively correlated with $\mathrm{K}, \mathrm{Ca}$, and $\mathrm{Mg}$ in both source materials. RW also was positively correlated with $\mathrm{P}$ and negatively correlated with $\mathrm{Mn}$ and $\mathrm{Zn}$ in root tissue but was not related to variation in these elements in soil.

A regression analysis of RW with the six RN elements with which it was correlated (Table 3) was calculated to identify elements most responsible for variation in RW. Nonsignificant $(P>0.05)$ terms were deleted in sequence until only significant $(P \leq 0.05)$ ones remained. The resulting equation:

$$
\mathrm{RW}=2.5517+102.0801 \mathrm{Mg}-0.1879 \mathrm{Zn},
$$

with an $R^{2}$ of $0.64(P=0.001)$, indicated that RW responded positively to increases in root $\mathrm{Mg}$ but negatively to root $\mathrm{Zn}$.

The results presented in this report do not lead to a clear understanding of the nutritional needs of American ginseng as measured by root growth. The uncomplicated RW responses to soil lime and $\mathrm{P}$ additions (Table 1) were not easily interpreted in terms of the resulting soil chemistry and plant nutrition. Lime additions significantly affected several SF factors $(\mathrm{pH}, \mathrm{K}, \mathrm{Ca}$, $\mathrm{Mg}, \mathrm{Mn}, \mathrm{Zn}$ ); except for slightly influencing soil $\mathrm{Na}, \mathrm{P}$ additions affected only soil $\mathrm{P}$ (Table 2). However, the regression

Table 4. Root tissue nutrient response to three rates each of dolomitic limestone (lime) and $\mathrm{P}$ in a pot experiment with American ginseng.

\begin{tabular}{|c|c|c|c|c|c|c|c|c|c|}
\hline \multirow{2}{*}{$\begin{array}{l}\text { Addition } \\
\left(\mathrm{kg} \cdot \mathrm{m}^{-3}\right)\end{array}$} & \multicolumn{9}{|c|}{ Nutrient element } \\
\hline & $\mathrm{N}$ & $\mathrm{P}$ & $\mathrm{K}$ & $\mathrm{Ca}$ & $\mathrm{Mg}$ & $\mathrm{Mn}$ & $\mathrm{Cu}$ & $\mathrm{Zn}$ & $\mathrm{Fe}$ \\
\hline$\overline{\operatorname{Lime}^{z}}$ & & & $\%$ & & & \multicolumn{4}{|c|}{$\overline{p p m}$} \\
\hline 0.0 & 1.69 & 0.23 & 1.25 & 0.24 & 0.10 & 117 & 8.2 & 32 & 262 \\
\hline 4.42 & 1.76 & 0.28 & 1.44 & 0.29 & 0.12 & 20 & 8.3 & 23 & 241 \\
\hline 8.84 & 1.87 & 0.31 & 1.48 & 0.33 & 0.12 & 13 & 8.5 & 22 & 251 \\
\hline \multicolumn{10}{|l|}{$\mathrm{P}^{2}$} \\
\hline 0.0 & 1.68 & 0.23 & 1.34 & 0.27 & 0.11 & 45 & 8.6 & 25 & 213 \\
\hline 0.16 & 1.83 & 0.30 & 1.44 & 0.30 & 0.12 & 48 & 8.9 & 26 & 254 \\
\hline 0.32 & 1.81 & 0.30 & 1.41 & 0.30 & 0.12 & 44 & 7.4 & 24 & 286 \\
\hline \multicolumn{10}{|l|}{ Significancey } \\
\hline Lime & $\mathrm{L}^{\prime \prime}$ & $\mathrm{L}^{\mathrm{i}}$ & $\mathrm{L}^{\mathrm{a}} \mathrm{Q}^{\mathrm{h}}$ & $\mathrm{L}^{\mathrm{a}}$ & $L^{b}$ & $\mathrm{~L}^{a} \mathrm{Q}^{\mathrm{a}}$ & NS & $\mathrm{L}^{\mathrm{a}} \mathrm{Q}^{\mathrm{a}}$ & NS \\
\hline $\mathrm{P}$ & $L^{b}$ & $\mathrm{~L}^{\mathrm{b}} \mathrm{Q}^{\mathrm{c}}$ & NS & $\mathrm{Lc}^{\mathrm{c}}$ & NS & NS & $\mathrm{L}^{\mathrm{b}} \mathrm{Q}^{\mathrm{a}}$ & NS & $\mathrm{L}^{\mathrm{a}}$ \\
\hline $\mathrm{R}$ (lime) & $0.64^{a}$ & $0.72^{3}$ & $0.86^{\circ}$ & $0.82^{\mathrm{a}}$ & $0.57^{\mathrm{b}}$ & $0.99^{a}$ & NS & $0.92^{\mathrm{a}}$ & NS \\
\hline $\mathrm{R}(\mathrm{P})$ & $0.48^{b}$ & $0.64^{\mathrm{b}}$ & NS & $0.39^{\circ}$ & NS & NS & $0.82^{\circ}$ & NS & $0.72^{\mathrm{a}}$ \\
\hline
\end{tabular}

${ }^{\mathrm{z}}$ Rates applied to potting medium at initiation of the 4-year experiment.

${ }^{\mathrm{y}} \mathrm{L}=$ linear; $\mathrm{Q}=$ quadratic; $\mathrm{R}=$ multiple correlation coefficient.

${ }^{\text {NS,a,b,c }}$ Nonsignificant or significant at $P=0.001,0.01$ or 0.05 , respectively. 
equation relating RW to soil fertility [Eq. 1] implicated only soil $\mathrm{Ca}$ and $\mathrm{Na}$ as significant factors for explaining the $\mathrm{RW}$ response observed. Calcium is a major constituent of the form of lime used. Its concentration in the soil was linearly related to liming rate (Table 2) (as were $\mathrm{pH}, \mathrm{K}$, and $\mathrm{Mg}$ ) and could be largely responsible for the RW response attributed to lime (Table 1) or even to soil pH (Konsler, 1979, 1980).

However, the regression of RW on RN status [Eq. 2] implicated root $\mathrm{Mg}$ and $\mathrm{Zn}$ as the predominant predictors of root growth. Lime rate had a positive linear effect on root $\mathrm{Mg}$ as well as on root $\mathrm{Ca}, \mathrm{N}$, and $\mathrm{P}$, and caused a nonlinear, but positive, response in root $\mathrm{K}$ (Table 4). Each or all of these elements may have contributed to the increase in RW with liming rate (Table 1). The successive elimination of terms in the regression analysis involving these $\mathrm{RN}$ elements, except $\mathrm{Mg}$, probably resulted from the similarity of their response to lime and probable correlation among them.

The foregoing discussion presumes a relationship between ginseng root nutritional status and root growth, whereas foliar status may be more closely related to potential for growth. Ginseng roots arc sinks for storage of plant foods whose mineral nutritional status may differ from that of the foliage.

\section{Literature Cited}

Bakhuyzen, H.L. van de Sande. 1926. Growth and growth formulas in plants. Science 64:653-654.

Bear, F.E. (ed.). 1964. Chemistry of the soil. 2nd ed. Reinhold, New York.

Hartman, G.F. 1979. Ginseng culture in Wisconsin. Proc. 1st Natl. Ginseng Conf. Lexington, Ky. p. 66-69.

Khwaja, A., R. Roy, and M.A. Rouf. 1984. Ginseng (Panax quinquefolium L.) plant tissue, roots and soil testing for fertilizer rec- ommendations. Proc. 6th N. Amer. Ginseng Conf. Guelph, Ontario. p. $116-138$

Konsler, T.R. 1979. Research with American ginseng (Panax quinquefolium L.) in North Carolina. Proc. 1st Natl. Ginseng Conf. Lexington, Ky. p. 79-90.

Konsler, T.R. 1980. An update on research with American ginseng (Panax quinquefolium L.) in North Carolina. Proc. 2nd Natl. Ginseng Conf. Jefferson City, Mo. p. 68-77.

Konsler, T.R. 1982. Some responses of American ginseng (Panax quinquefolium L.) to kind of bed mulch and to plant spacing through four growing seasons. Proc. 4th Natl. Ginseng Conf., Lexington, Ky. p. 14-24.

Konsler, T.R. and J.E. Shelton. 1980. Some early influences of N, P, and $\mathrm{pH}$ on cultivated ginseng (Panax quinquefolium L.). HortScience 15(3):281. (Abstr.)

Nash, G.V. 1898. American ginseng; its commercial history, protection, and cultivation. USDA Bul. no. 16.

Pearson, R.W. and F. Adams (eds.). 1967. Soil acidity and liming (no. 12 in the series, Agronomy). Amer. Soc. Agron, Madison, Wis.

Roberts. C.R. and J. Richardson. 1981. Wild ginseng monitoring program in Kentucky: A three-year summary. Univ. of Kentucky, College of Agriculture Progress Rpt. 256.

Steel, R.G.D. and J.H. Torrie. 1960. Principles and procedures of statistics. McGraw-Hill, New York.

Stoltz, L.P. 1981. Effects of mineral elements on growth of American ginseng. Proc. 3rd Natl. Ginseng Conf. Asheville, N.C. p. 26-28.

Stoltz, L.P. 1982a. Leaf symptoms, yield, and composition of mineraldeficient American ginseng. HortScience 17(5):740-741.

Stoltz, L.P. 1982b. Mineral nutrition studies of American ginseng. Proc. 4th Natl. Ginseng Conf. Lexington, Ky. p. 27-30.

Ulrich, A. 1976. Plant analysis as a guide in fertilizing crops. Soil and plant tissue testing in California. Div. Agr. Sci. Univ. Calif. Bul. 1879. p. 1-4.

von Bertalanffy, L. 1957. Quantitative laws in metabolism and growth. Quart. Rev. Biol. 32:217-231. 